\title{
Suspensor Development in the Nun Orchid, Phaius tankervilliae
}

\author{
X. L. Ye; S. Y. Zee; Edward C. Yeung \\ International Journal of Plant Sciences, Vol. 158, No. 6. (Nov., 1997), pp. 704-712.
}

Stable URL:

http://links.jstor.org/sici?sici=1058-5893\%28199711\%29158\%3A6\%3C704\%3ASDITNO\%3E2.0.CO\%3B2-7

International Journal of Plant Sciences is currently published by The University of Chicago Press.

Your use of the JSTOR archive indicates your acceptance of JSTOR's Terms and Conditions of Use, available at

http://www.jstor.org/about/terms.html. JSTOR's Terms and Conditions of Use provides, in part, that unless you have obtained prior permission, you may not download an entire issue of a journal or multiple copies of articles, and you may use content in the JSTOR archive only for your personal, non-commercial use.

Please contact the publisher regarding any further use of this work. Publisher contact information may be obtained at http://www.jstor.org/journals/ucpress.html.

Each copy of any part of a JSTOR transmission must contain the same copyright notice that appears on the screen or printed page of such transmission.

JSTOR is an independent not-for-profit organization dedicated to and preserving a digital archive of scholarly journals. For more information regarding JSTOR, please contact support@jstor.org. 


\title{
SUSPENSOR DEVELOPMENT IN THE NUN ORCHID, PHAIUS TANKERVILLIAE
}

\author{
X. L. YE, S. Y. ZEE, AND EDWARD C. YEUNG'
}

South China Institute of Botany, Academia Sinica, Guangzhou, China 510650; Department of Botany, University of Hong Kong, Pokfulam Road, Hong Kong; and Department of Biological Sciences, University of Calgary, Calgary, Alberta T2N 1N4, Canada

\begin{abstract}
The suspensor of the Nun orchid (Phaius tankervilliae) consists of a single cell, which originates as follows: after fertilization, the zygote divides once, unequally, giving rise to a smaller terminal cell and a larger basal cell. At the two-celled stage, a prominent cortical array of microtubules is present in the basal cell. The actin filaments are more centrally located within the cell having a perinuclear arrangement, and some actin material is also present at the micropylar end of the basal cell. After the basal cell divides one more time, the cell near the micropyle enlarges and differentiates into the suspensor cell. The enlargement of the suspensor results primarily from vacuolation. Characteristic organization of the cytoskeletal elements can be found at the time of cell enlargement. The actin filaments are localized in the cortical region of the cell, while the microtubules become internalized, forming a perinuclear array with extensions toward the poles of the cell. The final structural event in the development of the suspensor is the extension of the suspensor cell through the inner integument into the outer integument. At this stage, a cortical array of microtubules once again reappears. The cortical microtubules of the suspensor near the embryo proper are arranged transversely while those near the tip portion of the suspensor are aligned parallel to the long axis of the cell. The actin filaments remain unchanged and appear as a netlike framework located in the cell cortex. As the embryo matures, the cytoskeletal elements become disorganized and defined structures cannot be discerned.
\end{abstract}

\section{Introduction}

The suspensor is an embryonic organ and is essential to embryo development (Yeung and Meinke 1993). Although the structural characteristics of suspensors from different species have been detailed, little information is available about the cytoskeleton of the suspensor during its development. As the suspensor is normally firmly embedded within the seed coat, it is difficult to isolate it from the seed. This might have limited the study of the suspensor to conventional microscopy only. With the improvement in isolation techniques in conjunction with the use of confocal laser scanning microscopy, the study of the cytoskeleton of cells and organs became possible. Recent success in the study of the cytoskeleton of whole embryo sacs (Webb and Gunning 1991; Zee and Ye 1995; Ye et al. 1996) is a good example. We utilized a similar approach to study the cytoskeleton organization in the Nun orchid, Phaius tankervilliae, suspensor.

The small size of orchid embryos makes them unique among flowering plants in terms of embryo development. The reduction in size of the embryos, the usual lack of cotyledons, the absence of a welldefined endosperm, and the simple seed coat structure are some of the unique features of mature orchid seeds (Arditti 1992): Furthermore, it is known that orchids have different embryo development patterns, especially in the suspensor morphology (Swamy 1949). The Nun orchid was chosen for this study because the suspensor of this species consists of a single large cell and because the embryo can be readily isolated from the seed coat. Therefore, this orchid species provides a simple system to study the cytoskeletal elements dur-

${ }^{1}$ Author for correspondence and reprints. Telephone 403-2207186; fax 403-289-9311; E-mail yeung@acs.ucalgary.ca.

Manuscript received February 1997; revised manuscript received May 1997. ing the development of the suspensor in a flowering plant.

\section{Material and methods}

\section{Plant}

Developing fruits of Phaius tankervilliae (Banks ex l'Herit) Bl. were collected from greenhouse-grown plants maintained at the South China Institute of Botany at Guangzhou, China. Fruits were collected from May to August over a 2 -yr period. Approximately 50 developing fruits were gathered for this study. Seeds from freshly collected fruits were utilized for histological and immunological studies. About 60 seeds were processed from each fruit for microtubule and actin staining.

\section{LIGHT MICROSCOPY}

Sections of developing fruits were fixed in $1.6 \%$ paraformaldehyde and $2.5 \%$ glutaraldehyde in $50 \mathrm{mM}$ phosphate buffer and processed as detailed in Yeung (1987). The tissue was infiltrated with and embedded in Historesin (Leica Canada, Toronto; Yeung 1987; Yeung and Law 1987). Serial sections, $2 \mu \mathrm{m}$ thick, were cut using glass knives on a Reichert 2040 Autocut microtome. The sections were stained with periodic acid-Schiff's reaction (PAS) and counterstained with toluidine blue O (TBO; Yeung 1984). The presence of the cuticle was detected using Nile red as detailed in Yeung et al. (1996). The sections were stained with $1 \mu \mathrm{g} \mathrm{mL}-1$ of Nile red (Kodak, Rochester, N.Y.) for $10 \mathrm{~min}$, briefly washed in distilled water, and mounted in water containing $0.1 \%$ n-propyl gallate (Sigma), an antifading compound. The fluorescence pattern was examined using a Leica Aristoplan epifluorescence microscope.

\section{IMMUNOLOGICAL STAINING OF MICROTUBULES}

Developing seeds were dissected and fixed immediately in freshly prepared $3.7 \%$ paraformaldehyde, buffered with microtubule stabilizing buffer (MSB1: $5 \mathrm{mM}$ EGTA, $5 \mathrm{mM}$ $\mathrm{MgSO}_{4}$, and $100 \mathrm{mM}$ Pipes, $\mathrm{pH}$ 6.9) for $1 \mathrm{~h}$ at room temperature (Zee and Ye 1995). The seeds were washed three times with phosphate buffered saline (PBS) and then di- 
gested with a solution containing $1 \%$ cellulase (Sigma), $0.2 \%$ pectinase (Sigma), and $1 \%$ macerozyme (Calbiochem) in MSB2 buffer pH 5.6 ( $2 \mathrm{mM}$ EGTA, $1 \mathrm{mM} \mathrm{MgSO}_{4}, 0.4$ $\mathrm{M}$ mannitol, and $100 \mathrm{mM}$ Pipes) at $37^{\circ} \mathrm{C}$. The digestion time varied from $1 \mathrm{~h}$ for young developing embryos to $30 \mathrm{~min}$ for mature embryos. The digested samples were placed onto a poly-L-lysine coated coverglass. Another coverglass was placed on top of the seeds and flattened slightly. The samples were subsequently treated at room temperature with a $3 \%$ Nonidet P-40 solution to permeabilize the cells. Younger developing embryos were treated for $40 \mathrm{~min}$ while mature embryos were treated for $20 \mathrm{~min}$. In general, younger developing seeds required a longer time of treatment as the embryos were covered by several layers of tightly packed seed coat cells. The samples were then washed in PBS and treated with sodium borohydrate $(1 \mathrm{mg} / \mathrm{mL})$ in PBS for 15 min and rewashed in PBS prior to antibody staining. The preparations were stained using mouse monoclonal anti- $\alpha$ tubulin (Sigma T9026, $1: 500$ dilution) for $2 \mathrm{~h}$ at $37^{\circ} \mathrm{C}$, followed by staining with the FITC conjugated antimouse IgG (Sigma F0257, 1:16 dilution) for $40 \mathrm{~min}$ at $35^{\circ} \mathrm{C}$. Control experiments were conducted as follows: (1) omission of the primary antibody, (2) omission of the secondary antibody, and (3) omission of both antibodies. No staining was detected in any of the control experiments. After staining with the secondary antibody, all preparations were washed in PBS and subsequently mounted in an antifadent mounting solution (Citifluor, London). The preparations were examined using a BioRad MRC-600 confocal laser scanning microscope. The images were captured and processed by computer. They were then photographed and recorded on Kodak T-Max 100 film.

\section{STAINING OF ACTIN FILAMENTS}

The seeds were fixed and digested with the digestion solution as indicated above; however, a 20-min digestion time was sufficient. After digestion, the samples were washed with PBS containing $10 \%$ sucrose. The seeds were stained with a solution containing $4 \mu \mathrm{g} / \mathrm{L}$ FITC-Phalloidin (Sigma P5282), 5\% DMSO, $10 \%$ sucrose, $5 \mathrm{mM}$ EGTA, and 100 $\mathrm{mM}$ potassium phosphate buffer, $\mathrm{pH} 7.2$ for $2-4 \mathrm{~h}$. The samples were examined, without washing, using a BioRad MRC-600 confocal laser scanning microscope as above.

\section{Results}

The zygote had an elongated shape. The nucleus was located toward the chalazal end and a distinct vacuole was found toward the micropylar end (fig. 1). Endosperm failed to develop in this species. The nu- clei within the endosperm cavity formed a polar chalazal complex (fig. 2), and these nuclei would eventually disintegrate as the embryo developed. The first division of the zygote was unequal, giving rise to a smaller terminal cell and a larger basal cell. The terminal cell was more densely cytoplasmic, while large vacuoles were present in the elongated basal cell (fig. 2). At this two-celled stage, differences in the distribution of actin filaments and microtubules could be observed in the basal cell. The actin filaments were found to congregate around the nucleus, especially near the lower surface of the nucleus toward the micropylar end (fig. 3). Furthermore, a large amount of actin was located in the base of the cell that was in contact with the integument (fig. 3). The microtubules were more abundant in the upper part of the basal cell. They were oriented perpendicular to the long axis of the cell in the cell cortex (figs. 4, 5). In a median optical section, some microtubules were also found near the nucleus similar to that of the actin filaments (fig. 4). However, clearly defined microtubules were absent from the basal end of the cell near the micropyle.

The terminal cell enlarged, divided once transversely, and resulted in a three-celled embryo (fig. 6). This was soon followed by an anticlinal division occurring in the cell at the terminus, giving rise to a four-celled embryo (fig. 7). At this time, the basal cell near the micropyle divided once again, unequally (fig. 7). The smaller upper cell will become part of the embryo proper and the larger cell at the base will be the single large suspensor cell (fig. 8).

Vacuoles began to appear in the cytoplasm of the suspensor cell in preparation for cell expansion (fig. 9). They first appeared in the upper and lower ends of the cell (fig. 9). At this time, changes in the distribution of the cytoskeletal elements could also be observed. In a median optical section through the suspensor cell, little actin material was present in the internal cytoplasm (fig. 10). Instead, the actin filaments were found to localize in the cortical region of the cell and they had a netlike distribution (fig. 11). In addition, as with the two-celled embryo stage, actin was found to concentrate near the micropylar end of the suspensor cell (figs. 10,11). At this early vacuolation

Figs. 1-8 Fig. 1, A median longitudinal section showing a zygote (arrowhead). The nucleus is located toward the chalazal end, while a large vacuole is located at the micropylar end of the cell. Scale bar $=20 \mu \mathrm{m}$. Fig. 2, The first division of the zygote results in the formation of a smaller terminal cell and a large basal cell. The polar chalazal complex (arrowhead): the chalazal nuclei, the polar nuclei, and one of the male nuclei remain free in the cytoplasm. However, these nuclei eventually disintegrate. Endosperm fails to develop in this species. Scale bar $=20 \mu \mathrm{m}$. Fig. 3, A confocal image of actin distribution at the two-celled stage. In the basal cell, the actin filaments congregate around the nucleus (arrowhead) and the micropylar end of the cell (arrow). Scale bar $=25 \mu \mathrm{m}$. Fig. 4 , A median optical section showing the distribution of microtubules at the two-celled stage. In the basal cell, microtubules (arrowhead) are concentrated near the upper part of the cell and are located in the cortical region of the cell As a result, few microtubules are present in the central region of the cell. Scale bar $=$ $25 \mu \mathrm{m}$. Fig. 5, An optical section of the same embryo taken near the cell wall showing the orientation of the microtubules. The microtubules (arrowhead) are oriented perpendicular to the long axis of the cell. Scale bar $=25 \mu \mathrm{m}$. Fig. 6, The terminal cell divides once, and this results in the formation of a three-celled embryo. Scale bar $=20 \mu \mathrm{m}$. Fig. 7, The basal cell divides once (arrowhead), and the upper cell will incorporate into the embryo proper. The lower cell near the micropyle will differentiate into the suspensor. Scale bar $=20 \mu m$. Fig. 8 , Anticlinal divisions occurring in the terminal tiers of cells results in the enlargement of the embryo proper. No further division takes place in the suspensor cell (arrowhead). Scale bar $=20 \mu \mathrm{m}$. 

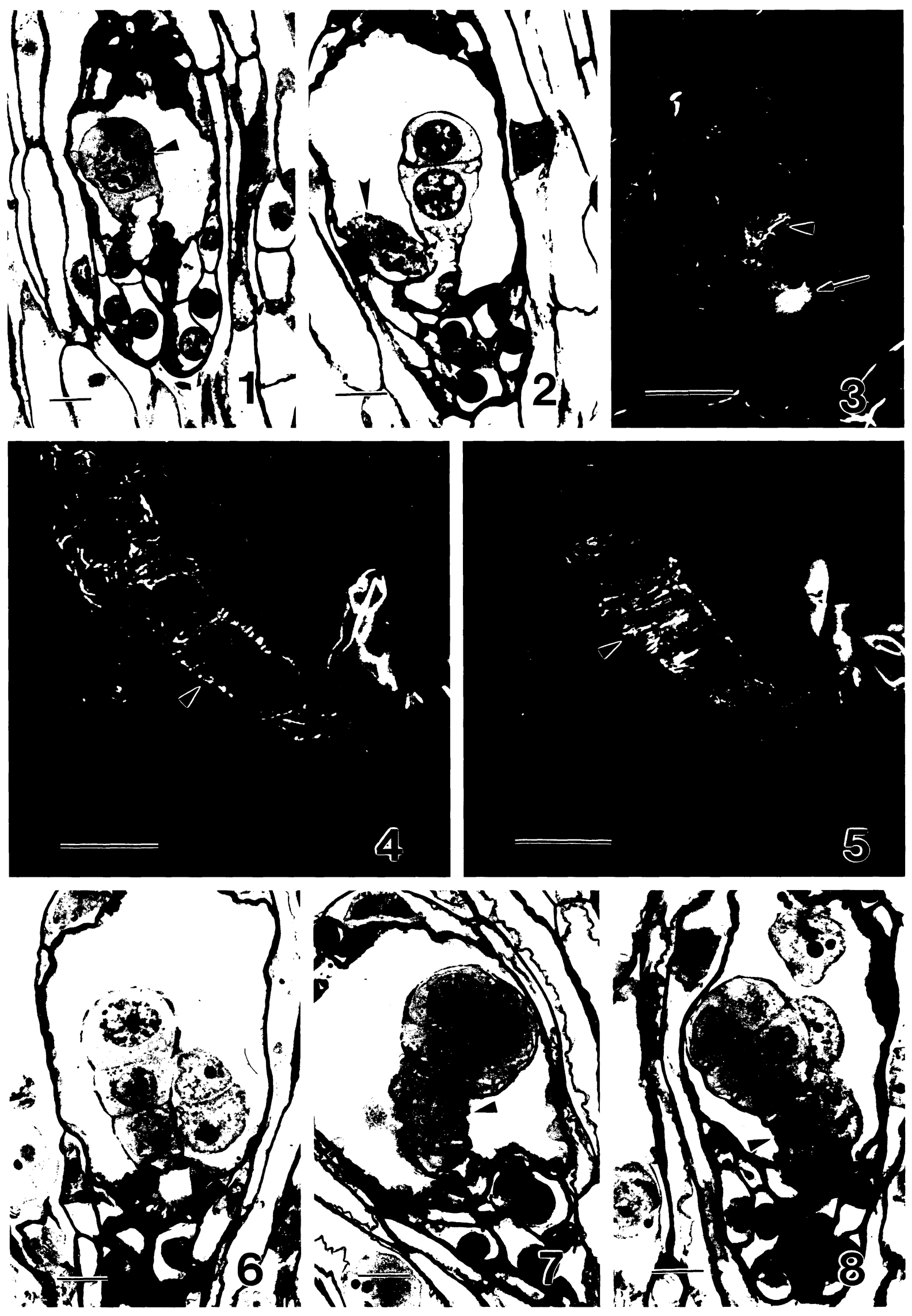


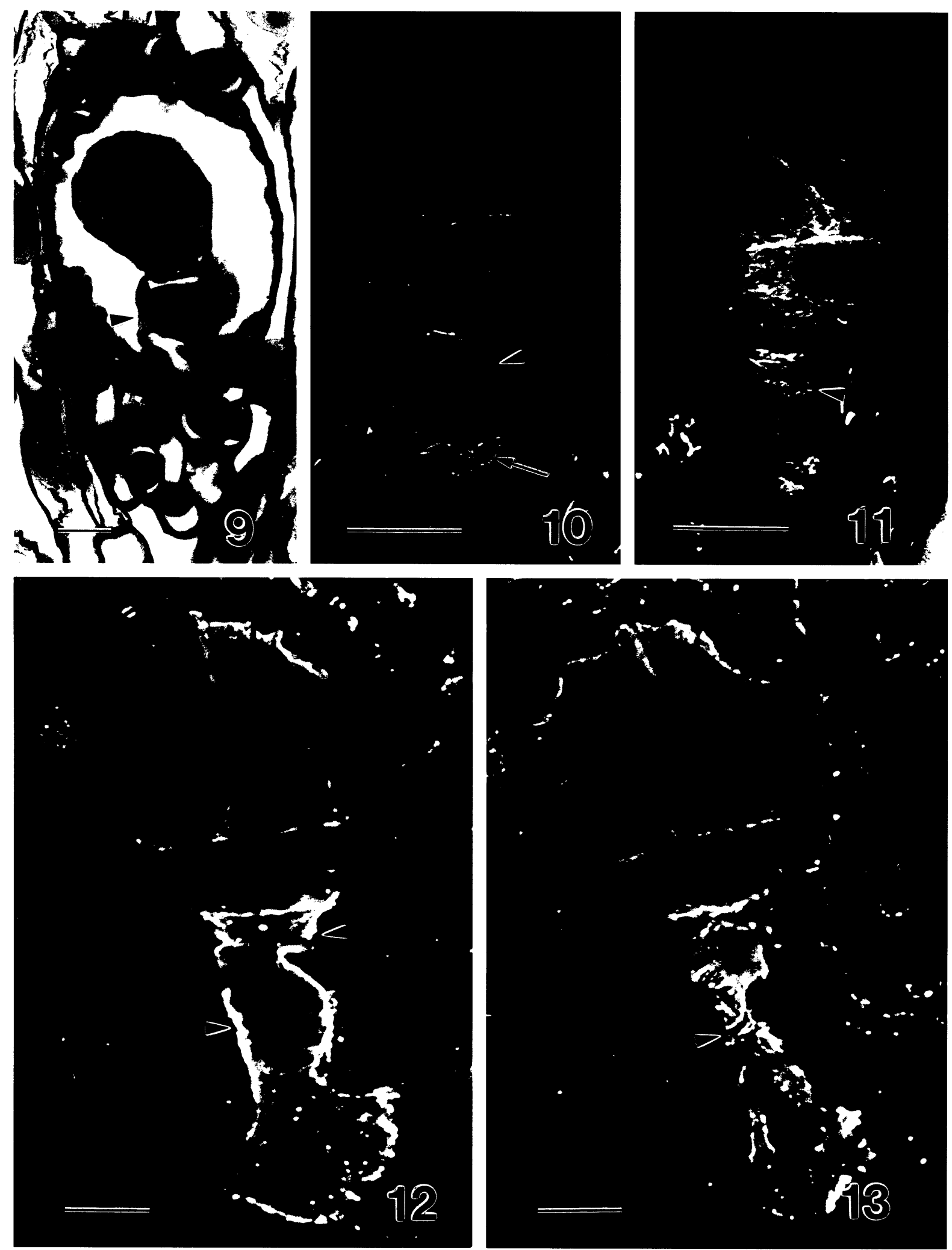

Figs. 9-13 Fig. 9, A longitudinal section showing the location of the vacuoles in the suspensor (arrowhead). Vacuoles begin to occur at both the apical and basal ends of the cell. Scale bar $=20 \mu \mathrm{m}$. Fig. 10, A confocal image showing a median section through the suspensor cell at a stage similar to fig. 9. The actin filaments are located at the cortical region (arrowhead) and the basal end of the cell (arrow). Scale bar $=25 \mu \mathrm{m}$. Fig. 11, An optical section of the same embryo taken near the cell wall showing the network of actin filaments (arrowhead) near the wall. Scale bar $=25 \mu \mathrm{m}$. Fig. 12, A confocal image showing a median section through the suspensor cell during the cell expansion phase of development. The microtubules (arrowheads) are located near the cortical region in the upper portion of the cell near the embryo proper. Scale bar $=10 \mu \mathrm{m}$. Fig. 13, An optical section of the same embryo taken near the cell wall showing the netlike pattern of microtubules (arrowhead) near the cell wall. Scale bar $=10 \mu \mathrm{m}$. 


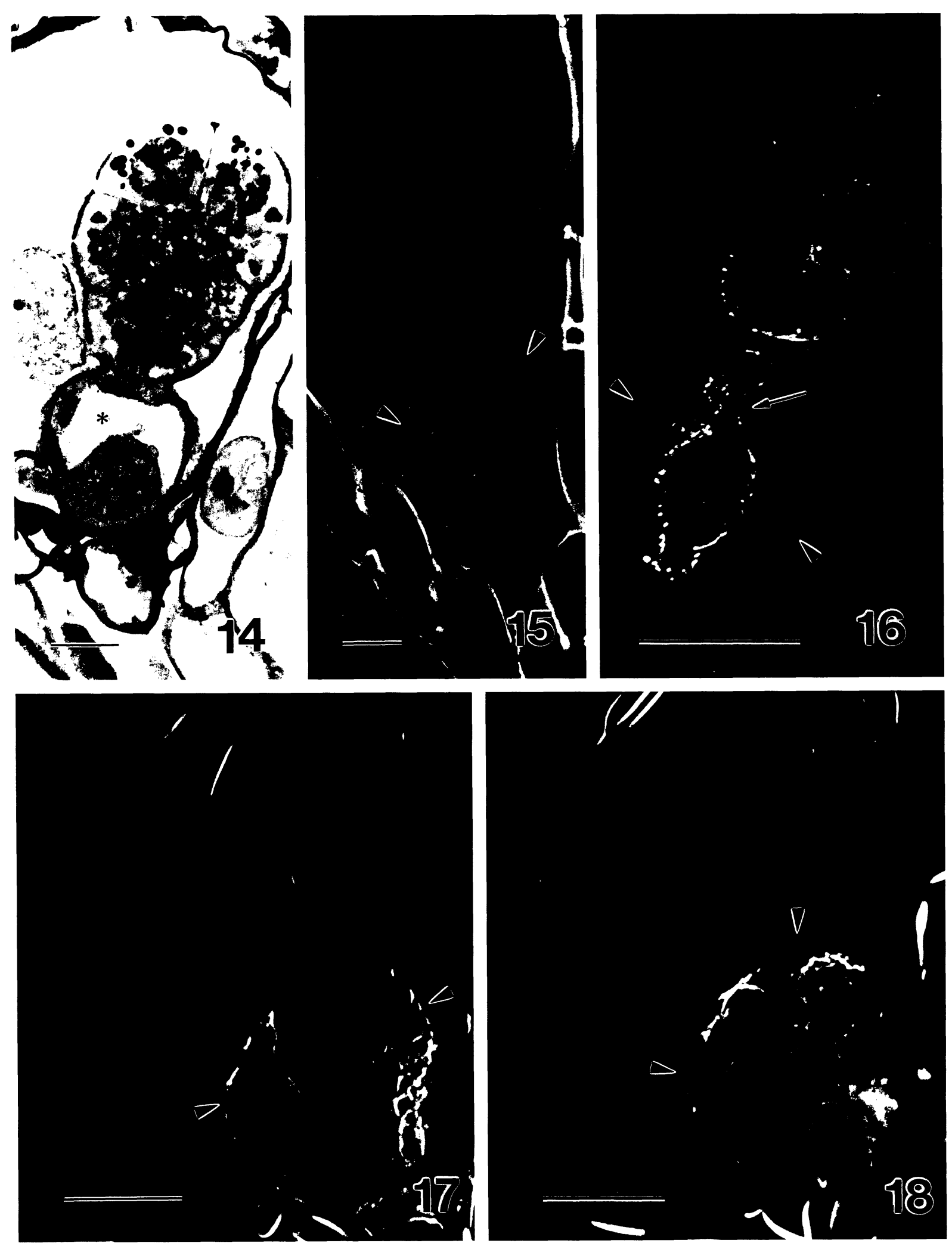

Figs. 14-18 Fig. 14, A light micrograph showing the enlargement phase of the suspensor. The vacuole (*) begins to enlarge and takes on a rounded appearance. Scale bar $=20 \mu \mathrm{m}$. Fig. 15, A light micrograph showing the fluorescence pattern after Nile red staining. The embryo proper and the exposed portion of the suspensor cell (arrowheads) give a positive reaction indicating the presence of a cuticle. Scale bar $=$ $20 \mu \mathrm{m}$. Fig. 16, A confocal micrograph showing the distribution of microtubules (arrow) within the suspensor cell at a stage similar to fig. 14. The microtubules are centrally located around the nucleus, and they also extend toward the embryo proper. The microtubules are oriented along the long axis of the cell. Microtubule is not present in the cortical region of the cell (arrowheads) at this time. Scale bar $=25 \mu \mathrm{m}$. Fig. 17, Optical section showing the distribution of actin filaments (arrowheads) in the expanding suspensor cell. A network of actin filaments 
stage, the distribution of microtubules was similar to that of the basal cell of the two-celled embryo with more microtubules localizing in the upper part of the suspensor cell (figs. 12,13). In an optical section taken at the cortical region near the wall, the microtubules were obliquely arranged (fig. 13). Clearly defined microtubules were absent from the base of the suspensor cell.

As development progressed, periclinal divisions occurred within each cell of the embryo proper, resulting in an increase in the size of the embryo (fig. 14). The outer cell walls of the embryo that were exposed to the endosperm cavity gradually thickened. This included the exposed part of the suspensor cell wall. These outer walls gave a blue color when stained with the toluidine blue $\mathrm{O}$ stain, indicating that a phenolic substance was present in the wall. These cell walls also reacted positively to Nile red, giving a strong fluorescence, indicating the presence of a cuticle (fig. 15). For the suspensor cell wall that was abutting to the integument, the wall gave a purple color when stained with toluidine blue $\mathrm{O}$, and it reacted negatively to Nile red, indicating that the cell wall lacked a cuticle.

The suspensor cell continued to enlarge. A single large vacuole appeared within the cell, and this resulted in the widening of the suspensor cell (fig. 14). At this time, the microtubules took on a different distribution pattern. They were found distributed around the nucleus with more microtubules radiating toward the upper and lower ends of the suspensor cell (fig. 16). Cortical microtubules were not present as indicated in a median optical section through the suspensor cell (fig. 16). The actin filaments, however, formed a prominent network of filaments occupying the cortical regions of the cell (figs. 17, 18). Again, at the micropylar end of the suspensor cell, a high concentration of actin filaments was present (figs. 17, 18).

In the final phase of suspensor development, the suspensor cell continued to expand, and eventually it protruded beyond the inner integument and established direct contact with seed coat cells originated from the outer integument (fig. 19). It continued to grow toward the micropyle, but it never grew beyond the outer integument of the seed coat. The microtubules once again reappeared in the cortical region of the suspensor cell. Near the embryo proper, a band of transverse microtubules became the dominant feature (fig. 20). Near the tip of the suspensor cell, a few axially oriented microtubules were present (fig. 20). Little change could be seen in the distribution of actin filaments at this time. The actin filaments remained as a fine meshwork of filaments in the cortical region of the suspensor cell (fig. 22).
As the embryo matured, the cytoskeletal elements began to break down. The tubulin appeared as fluorescent spots without discernable structure (fig. 21). The actin appeared as a weak fluorescence, again with no defined structure (fig. 23).

\section{Discussion}

The simple structure of the Nun orchid embryo provides a unique opportunity in the study of the cytoskeleton of the suspensor. Judging from the changes in the cell shape and size, the development of the suspensor in the Nun orchid can be divided into three phases. During the initial phase of the suspensor development, the basal cell first elongates and extends into the endosperm cavity. This is followed by the enlargement of the suspensor cell and finally the extension growth of the suspensor cell through the inner integument of the seed coat. These three phases of growth coincide with characteristic distributions of cytoskeletal elements.

During the first phase of growth, the microtubules tend to localize in the chalazal end of the basal cell. These microtubules form a cortical array and orient transversely to the long axis of the cell; few internal microtubules are present within the cytoplasm. This finding is similar to that reported by Webb and Gunning (1991) in the developing suspensor of the Arabidopsis embryo. In plant cells, a cortical array of microtubules is usually present. This cortical array of microtubules is believed to function in the maintenance of cell shape and may play a role in cell wall synthesis (Cyr 1994; Webb and Gunning 1994). In the Nun orchid, the prominent localization of microtubules at the two-celled stage of embryo development indicates that the microtubules may contribute to maintaining the elongated shape of the basal cell. Since the microtubules are distributed transversely to the long axis of the cells, this may result in the preferential elongation of the basal cell into the endosperm cavity. The lack of a prominent network of cortical microtubules during the enlargement phase coincides with the rounding up of the suspensor cell.

At the two-celled stage, the distribution of the actin filaments differs significantly from that of the microtubules. The actin filaments are localized within the cytoplasm, and few can be found in the cortical region. Furthermore, a large amount of actin is present at the base of the cell near the micropyle. Microfilaments are normal components of plant cells (Parthasarathy et al. 1985), and their importance in plant growth and development is well recognized (Derksen et al. 1990). In the Nun orchid, the perinuclear distribution and the longitudinal array of actin filaments indicate that, besides other functions, they may play a role in nuclear positioning. The high concentration of actin near the

$\leftarrow$

is present in the cortical region of the cell. Scale bar $=25 \mu \mathrm{m}$. Fig. 18, Similar to fig. 16, this optical section indicates a similar pattern of actin filament (arrowheads) distribution in the upper part of the cell. Scale bar $=25 \mu \mathrm{m}$. 

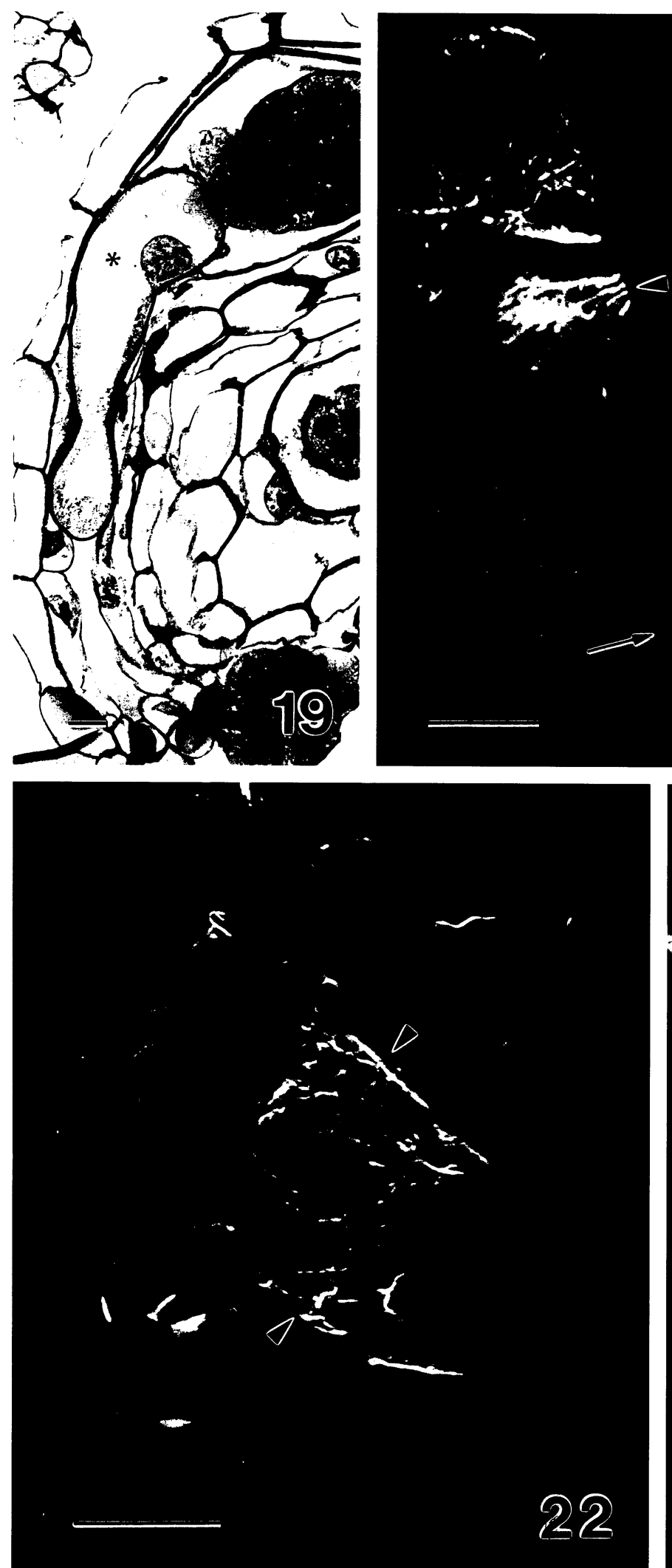
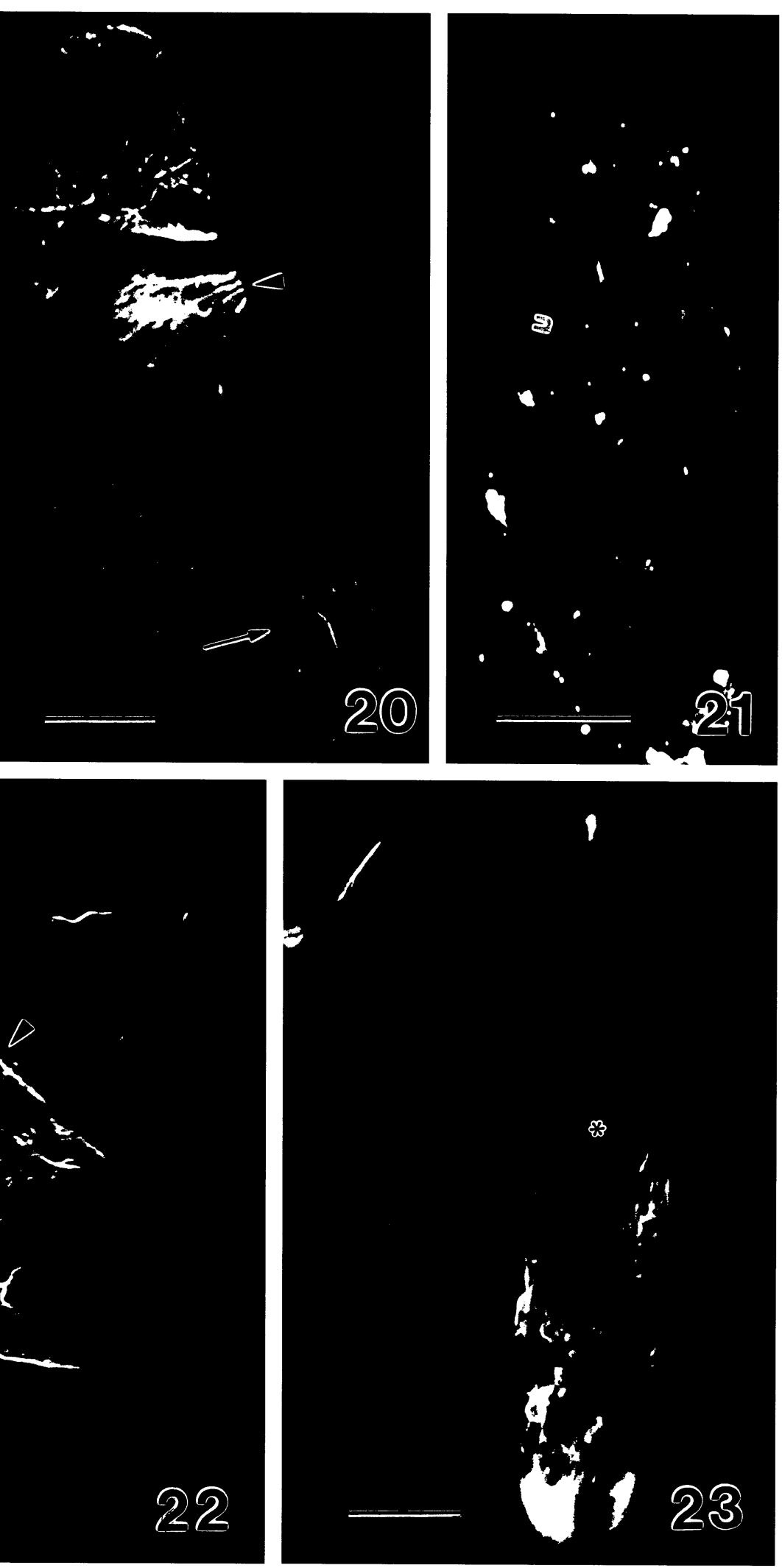

Figs. 19-23 Fig. 19, A light micrograph showing the elongation phase of the suspensor. The suspensor $(*)$ begins to extend beyond the inner integument. However, it never extends beyond the seed coat. Scale bar $=20 \mu \mathrm{m}$. Fig. 20, An optical section showing the distribution of microtubules within the elongated suspensor cell. In the upper portion, the microtubules (arrowhead) tend to orient perpendicular to the long axis of the cell, and in the tip portion, the microtubules (arrow) tend to orient in the same direction of the long axis. Scale bar $=10$ $\mu \mathrm{m}$. Fig. 21, At the time of maturation and desiccation, a defined microtubular structure cannot be discerned. Scale bar $=25 \mu \mathrm{m}$. Fig. 22 , 
micropylar end of the cell is unusual, and the functional significance of this is not known. However, this pattern of distribution is similar to that of the pollen at the onset of pollen germination. Actin filaments converge toward the aperture when the pollen tube subsequently emerges (Heslop-Harrison and HeslopHarrison 1986; Tiwari and Polito 1988, 1990). In the Nun orchid, this high concentration of actin material may have interacted with the cell wall and created a predetermined site for the elongation of the suspensor later on.

In the developing embryo, after the second round of division, no further division occurs within the basal cell. The suspensor differentiates directly from the cell at the micropylar end of the embryo. At this time, the suspensor enlarges in size prior to its extension through the micropyle. The increase in the size of the vacuoles forms the driving force behind the cell enlargement process. At the early stage of vacuolation, actin filaments begin to appear in the cortical region and a prominent cortical array of microtubules is still present. As the suspensor cell enlarges further, the microtubules are absent from the cortical region and they form a perinuclear array with extensions toward the apical and basal part of the cell. This pattern of microtubule arrangement indicates that the microtubules are responsible for nuclear positioning, and their extension along the long axis of the cell indicates that they can provide part of the driving force for the subsequent extension process.

The actin filaments form a prominent cortical network as the suspensor cell expands in size. This morphology and pattern of distribution is similar to those observed in protonemata of the moss Ceratodon (Walker and Sack 1995). In Ceratodon, the actin filaments appear to play a role in the regulation of plastid zonation (Walker and Sack 1995). The network of actin filaments in the Nun orchid can play a similar role in the regulation of organelle distribution since the ground cytoplasm of the suspensor cell is confined to the cortical area. Furthermore, with the absence of cortical microtubules, the actin filaments can also reinforce the cell wall in order to prevent a continuous expansion of the suspensor within the endosperm cavity.

The final extension process of the suspensor through the micropyle at a defined point is certainly a complex process. The driving force behind the extension process has to be the increase in the turgor pressure within the suspensor cell. However, with the information at hand, the cell wall characteristics and the cytoskeletal elements can certainly play a role in ensuring that the suspensor cell extends through its inner integument. The thickened cell wall and the presence of cuticular material at the upper part of the suspensor cell can prevent further expansion of the suspensor cell into the endosperm cavity. These wall features, together with the cytoskeletal elements, can act as an anchor for suspensor elongation. Since the cell wall near the micropyle remains thin, a further increase in turgor pressure would generate sufficient force to lead to extension growth at this "weaker" spot within the suspensor cell.

Cuticular substance has been shown to be present in developing embryos and is absent from the suspensor cells (Rodkiewicz et al. 1994; Lackie and Yeung 1996; Yeung et al. 1996). The presence of the cuticular material in the exposed part of the suspensor cell in the Nun orchid indicates the uniqueness of the suspensor development in this species. Cutin biosynthesis is a complex process and involves extra- and intracellular enzyme activities (Holloway 1982). In the absence of endosperm development, the Nun orchid embryo is directly exposed to the seed cavity. This unique embryonic environment may allow for the synthesis and deposition of cuticular material on the exposed surface of the embryo.

As the suspensor continues to elongate, a cortical array of microtubules reappears. More microtubules are concentrated near the upper part of suspensor near the embryo proper. This distribution indicates that the microtubule-directed wall deposition reinforces the upper part of the suspensor cell, restricting lateral expansion at that location. Toward the tip, a longitudinal profile is evident, indicating that the microtubules may aid in the elongation process at the tip. The actin filaments, however, maintained a network distributed near the cortical region of the cell. Again, this can strengthen the cell wall as the suspensor elongates.

Although the suspensor consists of only a single cell in the Nun orchid, this study indicates the complex changes in the cytoskeletal elements during its development.

\section{Acknowledgments}

This research was supported by an operating grant from the Natural Sciences and Engineering Research Council to Edward C. Yeung and one from the Croucher Foundation to S. Y. Zee.

An optical section showing the distribution of actin filaments within the elongated suspensor cell. The actin filaments (arrowheads) form a network in the cortical region of the cell. Scale bar $=25 \mu \mathrm{m}$. Fig. 23, At the time of maturation and desiccation, a defined actin filament structure is absent from the cytoplasm of the suspensor cell $(*)$. Scale bar $=25 \mu \mathrm{m}$. 


\section{literature cited}

Arditti J 1992 Fundamentals of orchid biology. Wiley, New York.

Cyr RJ 1994 Microtubules in plant morphogenesis: role of the cortical array. Annu Rev Cell Biol 10:153-180.

Derksen J, FHA Wilm, ES Pierson 1990 The plant cytoskeleton: its significance in plant development. Acta Bot Neerl 39:1-18.

Heslop-Harrison J, Y Heslop-Harrison 1986 Actin during pollen germination. J Cell Sci 86:1-8.

Holloway PJ 1982 The chemical constitution of plant cutins. Pages 45-85 in DF Cutler, KL Alvin, CE Price, eds. The plant cuticle. Academic Press, London.

Lackie S, EC Yeung 1996 Zygotic embryo development in Daucus carota. Can J Bot 74:990-998.

Parthasarathy MV, TD Perdue, A Witztum, J Alvernaz 1985 Actin network as a normal component of the cytoskeleton in many vascular plant cells. Am J Bot 72:1318-1323.

Rodkiewicz B, B Fyk, E Szczuka 1994 Chlorophyll and cutin in early embryogenesis in Capsella, Arabidopsis, and Stellaria investigated by fluorescence microscopy. Sex Plant Reprod 7:287289.

Swamy BGL 1949 Embryological studies in the Orchidaceae. II. Embryology. Am Midl Nat 41:202-232.

Tiwari SC, VS Polito 1988 Spatial and temporal organization of actin during hydration, activation, and germination of pollen in Pyrus communis L.: a population study. Protoplasma 147:5-11.

1990 The initiation and organization of microtubules in germinating pear (Pyrus communis L.) pollen. Eur J Cell Biol 53: 384-389.
Walker LM, FD Sack 1995 Microfilament distribution in protonemata of the moss Ceratodon. Protoplasma 189:229-237.

Webb MC, BES Gunning 1991 Microtubular cytoskeleton during development of the zygote, proembryo and free-nuclear endosperm of Arabidopsis thaliana (L.) Heynh. Planta 184:187-195.

1994 Cell biology of embryo sac development in Arabidopsis. Pages 461-485 in EG Williams, AE Clarke, RB Knox, eds. Genetic control of self-compatibility and reproductive development in flowering plants. Kluwer, Dordrecht.

Ye YL, E Yeung, SY Zee, SH Tung 1996 Confocal microscopy observations on microtubular cytoskeleton changes during megasporogenesis and megagametogenesis in Phaius tankervilliae (Aiton) Bl. Acta Bot Sin 38:677-685.

Yeung EC 1984 Histological and histochemical staining procedures. Pages 689-697 in IK Vasil, ed. Cell culture and somatic cell genetics of plants. Academic Press, Orlando, Fla.

1987 Development of pollen and accessory structures in orchids. Pages 193-226 in J Arditti, ed. Orchid biology: reviews and perspectives. Vol 4. Cornell University Press, Ithaca, N.Y.

Yeung EC, SK Law 1987 Serial sectioning techniques for a modified LKB Historesin. Stain Technol 62:147-153.

Yeung EC, DW Meinke 1993 Embryogenesis in angiosperms: development of the suspensor. Plant Cell 5:1371-1381.

Yeung EC, SY Zee, XL Ye 1996 Embryology of Cymbidium sinense: embryo development. Ann Bot 78:105-110.

Zee SY, XL Ye 1995 Changes in the pattern of organization of the microtubular cytoskeleton during megasporogenesis in Cymbidium sinense. Protoplasma 185:170-177. 